\title{
Rasa jako medium
}

Jacek Zwierzyński 


\section{Komentarze}

\section{Rasa jako medium ${ }^{1}$}

Jacek Zwierzyński

TEKSTY DRUGIE 2017, NR 5, S. 195-208

DOI: $10.18318 /$ td.2017.5.13

$\mathbf{T}$ rzeba by cierpieć na szczególnie głęboką ślepotę, by nie dostrzegać ciągłej obecności rasizmu we współczesnym świecie"2 - tym zdaniem W. J.T. Mitchell otwiera Wstęp książki Seeing Through Race, wydanej w 2012 r. przez Harvard University Press. Proponuje w niej nowe spojrzenie na kategorię rasy, usytuowane w obszarze badań nad kulturą wizualną i ikonologii rozumianej jako nauka o obrazach. Badacz przyznaje, że mimo odrzucenia jej przez naukę, rasa pozostaje zasadniczym pryzmatem postrzegania rzeczywistości społecznej w Stanach Zjednoczonych. Szeroka użyteczność pojęcia, od badań statystycznych po abstrakcyjną ksenofobiczną retorykę, oraz

1 Artykuł powstał w ramach pracy nad rozprawą doktorską, przygotowywaną pod kierunkiem dr hab. Agaty Jakubowskiej prof. UAM w Instytucie Historii Sztuki UAM. Dziękuję Promotorce za krytyczną lekturę pierwszej wersji tekstu.

2 W.J.T. Mitchell Seeing through race, Harvard University Press, Cambridge, MA-London 2012, s. XI.
Jacek Zwierzyński historyk sztuki, w IHS UAM pod kierunkiem dr hab. Agaty Jakubowskiej, prof. UAM przygotowuje rozprawę doktorską poświęconą relacji rasy i sylwetki jako konwencji obrazowania ciała we współczesnej sztuce amerykańskiej. Kontakt: jaczwierzynski@ gmail.com 
jego zadziwiająca dyspozycyjność współwystępują z konsensusem naukowym, że rasa nie ma źródeł w obiektywnej rzeczywistości. Czym zatem jest, skoro w podstawowym dla ludzkiego poznania procesie kategoryzacji może służyć opisowi każdej grupy i każdej jednostki według dowolnie dobranych kryteriów, zachowując jednocześnie swą autorytarną siłę i pozór racjonalności? Uznając rasę z a ó w no za iluzję, jak i rzeczywistość, Mitchell formułuje koncepcję rasy jako medium.

W.J.T. Mitchell jest jednym z najwybitniejszych współczesnych teoretyków mediów i wizualności, profesorem literatury angielskiej i historii sztuki na Uniwersytecie Chicagowskim i redaktorem naczelnym pisma „Critical Inquiry” od 1978 roku. W wydanej w 1994 roku książce Picture Theory przedstawił głośną koncepcję zwrotu obrazowego, dokonującego się w drugiej połowie XX wieku3. W swoich tekstach, z których część została już włączona do kanonu humanistyki, wielokrotnie podejmował problem społecznego funkcjonowania obrazów, sposobów budowania przez nie znaczeń, ich relacji ze słowem. W Seeing Through Race, z perspektywy rychłej klęski epoki postrasowej, włącza się w akademicką dyskusję o użyteczności koncepcji rasy. Mitchell podejmuje tezę Kwame Anthony'ego Appiaha z 1985 r.: „Prawda jest taka, że nie ma ras, nie ma nic na świecie, co mogłoby spełnić wszystko to, czego spełnienia wymagamy od »rasy «"4, i odczytuje ją à rebours: użyteczność i żywotność pojęcia wynika właśnie z tego, że kategoria rasy nie ma stabilnego oparcia w rzeczywistości. „Nie ma nic in ne go na świecie pisze badacz - co mogłoby spełnić wszystko to, czego spełnienia wymagamy od rasy"'.

Już sam tytuł książki, który należałoby tłumaczyć na „widzenie poprzez rasę", wskazuje perspektywę refleksji i kluczowe założenie teoretyczne. Mitchell nawiązuje w nim do Wyroczni niewinności Williama Blake’a, których fragment służy jako motto Wstępu:

3 Jak jednak sam podkreśla, zwrot obrazowy wyrażający się w nowych formach ikonoklazmu i ikonolatrii, "obsesja epoki nowoczesnej na punkcie widzenia i reprezentacji wizualnej", nie wyróżnia szczególnie współczesności na tle innych epok, lecz "jest tropem retorycznym, figurą mowy powtarzaną wielokrotnie od czasów starożytnych", pozwalającym dokonać "przeniesienia moralnej i politycznej trwogi na obrazy". W.J.T. Mitchell Czego chcq obrazy, przeł. Ł. Zaremba, Narodowe Centrum Kultury, Warszawa 2013, s. 374, 370.

4 A. Appiah The Uncompleted Argument: Du Bois and the Illusion of Race, "Critical Inquiry" Vol. 12, No 1 (Autumn, 1985), s. 35 .

5 W.J.T. Mitchell Seeing..., s. 14 . 
Łatwo w kłamstwo uwierzymy,

Gdy miast przez oko, okiem patrzymy. ${ }^{6}$

Truizmem jest stwierdzenie, że widzenie to podstawowy akt poznawczy w systemie logocentrycznym, wyobrażenie "oka" od zawsze stanowiło metaforę „umysłu”, a popęd ujmowania spojrzeniem stanowi paradygmat wiedzy. Mając to na widoku, Mitchell proponuje ujęcie rasy jako medium właściwego samemu spojrzeniu - zespołu filtrów poznawczych zapośredniczających widzenie. Badacz przyjmuje za Oksfordzkim Słownikiem Języka Angielskiego szeroką definicję „medium” jako „pośredniczącej materii”, czemu odpowiada najbardziej ogólne znaczenie terminu w języku polskim: „to, za pośrednictwem czego są przekazywane lub wyrażane jakieś treści"8. Według Mitchella rasa stanowi nie tyle „wyrażaną treść", przedmiot reprezentacji wizualnej czy językowej, ile - sama w sobie - medium i koncepcję ikoniczną. W tym ujęciu rasa jest tym, „p r z e z c o wi d z i my, jak rama, okno, ekran czy soczewka, raczej niż tym, n a co p a tr zy my. To zespół kognitywnych i konceptualnych filtrów, poprzez które mediowane są formy ludzkiej odmienności"9. Dlatego właściwym obiektem badań powinien stać się proces, „poprzez który rasa ulega «zwarciu» i «zagęszczeniu» w ten sposób, że zmienia się z medium postrzegania p o p r z e z - ramy widzenia j a k o - w kształt, obraz lub obiekt o właściwościach zmysłowych i byt jako taki"10. Niezwykle obiecująca koncepcja zarysowana przez Mitchella w pierwszych trzech rozdziałach, opartych na wykładach prowadzonych na Uniwersytecie Harvarda w 2010 roku, nie znajduje wyczerpującego rozwinięcia w studiach poświęconych poszczególnym „obiektom”, takim jak dzieła sztuki, mury i granice, krajobraz. Uzupełniające zasadniczą część książki eseje pozostawiają pewien niedosyt, co wydaje

6 Cytuję fragment wiersza w przekładzie Zygmunta Krukowskiego, "Strony" 1998 nr 1-2, s. 24; w oryginale: "We are led to Believe a Lie / When we see [with] not Thro' the Eye".

7 R. Braidotti Podmioty nomadyczne. Ucieleśnienie i różnica seksualna w feminizmie współczesnym, przeł. A. Derra, Wydawnictwa Akademickie i Profesjonalne, Warszawa 2009, s. 81-82, 118. Według Słownika języka polskiego PWN paradygmat to „1. przyjęty sposób widzenia rzeczywistości w danej dziedzinie, doktrynie itp."; red. M. Szymczak, t. 2, Wydawnictwo Naukowe PWN, Warszawa 1999, s. 576, podkreślenie moje.

8 Hasło "medium" 4, Nowy słownik języka polskiego, red. E. Sobol, Wydawnictwo Naukowe PWN, Warszawa 2002, s. 446.

9 W.J.T. Mitchell Seeing..., s. XII. 
mi się nie tylko nieuniknione, ale i być może pożądane przy zagadnieniu tej wagi. Pytanie badawcze pozostaje otwarte, problem - aktualny.

Mitchell już we Wstępie zaznacza, że ujęcie rasy jako medium wielu czytelnikom i czytelniczkom może wydać się osobliwe. $Z$ drugiej strony dla badaczy i badaczek zajmujących się tą problematyką - to koncepcja osobliwie bliska, niemalże oczywistość. Od dawna miała się „skrywać w zasięgu wzroku”, co najmniej od czasu użycia przez W.E.B. Du Boisa sugestywnej metafory zasłony (veil) w opisie doświadczenia czarnych Amerykanów i Amerykanek ${ }^{11}$. "Zaświtało mi wtedy, dosyć niespodziewanie, że jestem inny od pozostałych; albo podobny, być może, w sercu, życiu i pragnieniach, lecz odgrodzony od ich świata bezkresną zasłoną"12 - tak w rozpoczynającym eseju opublikowanych w 1903 roku The Souls of Black Folk Du Bois opisywał swoje pierwsze doświadczenie rasizmu. To błaha scena - w szkole biała dziewczynka odmówiła przyjęcia od niego wizytówki, jakimi dla zabawy wymieniały się dzieci. Lecz gdy raz ujrzał zasłonę, która zawsze-już była, doznał jej objawienia, nie mógł jej już nie dostrzegać. W Du Boisiańskiej metaforze rasa-rasizm sytuuje się $\mathrm{mi}$ ię zy podmiotem i przedmiotem spojrzenia, między podmiotem a obrazem samego siebie, w samym spojrzeniu. Zasłona, choć przyrodzona, to nie wrodzone cechy, predyspozycje psychiczne, ciemna skóra - lecz zespół filtrów poznawczych, projektowany szablon, obraz-ekran. Oblekająca czarnych, zapośredniczając i zniekształcając spojrzenie kierowane z obydwu stron, zasłona uniemożliwia nie tylko spotkanie twarzą w twarz. Niczym przed wyobrażonym lustrem - zaciemnia ogląd samego, samej siebie. Metafora łączy się z opisanym przez Du Boisa problemem p od wój nej św i a d o mo ści czarnych Amerykanów i Amerykanek - patrzących na siebie zawsze oczami Innego, nieustannie poddających się ocenie z perspektywy białego rasizmu.

Używając metafory zasłony, Du Bois przywołuje szereg wpisanych w nią znaczeń. Gdy pisze, że czarni widzą siebie samych „niejasno, jak przez zasłonę" („darkly as through a veil”), nawiązuje do Hymnu do miłości św. Pawła: „Teraz widzimy jakby w zwierciadle, niejasno; wtedy zaś [zobaczymy] twarzą w twarz: Teraz poznaję po części, wtedy zaś poznam tak, jak i zostałem poznany" $\left(1\right.$ Kor 13,12) ${ }^{13}$. Eschatologiczne odniesienie sytuuje rasizm w perspek-

11 
tywie sprawiedliwości, konstytuującej biblijną przeciwhistorię - u kresu: „Zedrze On na tej górze zasłonę, zapuszczoną na twarz wszystkich ludów, i całun, który okrywał wszystkie narody" (Iz 25,7). Lecz dla Du Boisa zasłona jest nie tylko tym, co uniemożliwia poznanie, filtrem błędnych schematów poznawczych, uprzedzeń - sama podwaja pole widzenia. Wykorzystując wieloznaczność słowa veil, niejako w suplemencie do Heglowskiej Fenomenologii ducha, socjolog stwierdzał, że „w tym amerykańskim świecie czarny [Negro] jest jak siódmy syn, w czepku urodzony [born with a veil] i obdarzony drugim wzrokiem"14. Mitchell zwraca uwagę, że Du Boisiańska metafora - zasłona, czepek, błona owodniowa - reprezentuje fundamentalne paradoksy rasy: ułatwia i utrudnia komunikację; powoduje ślepotę i obdarza jasnowidzeniem; sprawia bycie niewidzialnym przy jednoczesnej hiperwidzialności ${ }^{15}$. Tylko doświadczenie odmienności rasowej daje częściowy wgląd w wewnętrzne struktury niepojętego zjawiska, jakim jest rasizm.

Sięgając po definicję zaproponowaną przez Suta Jhally'ego, można opisać rasizm jako filozofię utrzymującą, że „istnieje naturalny związek między tym, jak ludzie wyglądają, różnicami koloru, włosów, kości, a tym, co myślą i robią. Jak są inteligentni, czy są dobrymi czy złymi sportowcami, dobrymi czy złymi tancerkami, dobrymi pracownikami, czy są cywilizowani czy nie. Rasiści wierzą, że te cechy wynikają nie z naszego środowiska, ale z naszych genów"16. Według Mitchella to rasizm jest Lacanowskim Realnym, materialnym faktem o złożonych, nie w pełni poznanych przyczynach, rasa zaś jego produktem, Symbolicznym-Wyobrażonym, kruchą rzeczywistością dającą mu wyjaśnienie i wyimaginowaną przyczynę $e^{17}$. Jako wytwór, a nie powód czy pretekst rasizmu, rasa w propozycji Mitchella może służyć jako okno na trudno uchwytną, zawiłą dynamikę tej ideologii'18.

Badacz co prawda uznaje potrzebę krytycznej dekonstrukcji pojęcia bądź zastępowania go terminami takimi jak etniczność, narodowość, cywilizacja czy kultura. Nie zgadza się jednak z zupełnym odrzuceniem kategorii rasy,

14 W.E.B. Du Bois The souls..., s. 2.

15 W.J.T. Mitchell Seeing..., s. 13.

16 Race, the floating signifier: Featuring Stuart Hall, reż. S. Jhally, 1997. Transkrypt dostępny online: http://www.mediaed.org/transcripts/Stuart-Hall-Race-the-Floating-Signifier-Transcript.pdf (22.11.2016).

17 W.J.T. Mitchell Seeing ..., s. 19.

18 Tamże, s. 32. 
proponowanym przez Appiaha, Paula Gilroya, Joshuę Glasgowa i innych teoretyków, uznając, że nie przyniesie to oczekiwanego kresu dyskryminacji. Niemożliwe okazało się, postulowane m.in. przez Roberta Milesa, analizowanie rasizmu „bez zniekształcającego pryzmatu zaszczepianego przez użycie pojęcia «rasy»"19. Dlatego przedmiotem analizy powinien stać się sam ten "zniekształcający pryzmat", rasa jako filtr, historia jego ustanawiania i funkcjonowanie. Nie sposób nie zgodzić się z Mitchellem, że kategoria rasy - inaczej niż teoria flogistonu po odkryciu tlenu - okazała się zbyt potężna, by ulec zapomnieniu ${ }^{20}$. W poszukiwaniu przyczyn jej pogrobowej żywotności szerokim badaniom należy poddać genealogię pojęcia, źródła i historię funkcjonowania teorii rasowych.

Antropologia fizyczna, od XVIII wieku rozwijana jako niezależna dyscyplina naukowa, przyjęła istnienie ras ludzkich za paradygmat, a właściwym celem badań uznała ich odkrycie i opisanie. W 1735 roku Linneusz, twórca naukowej klasyfikacji przyrodniczej, wprowadził geograficzny podział Homo sapiens na odmiany (varietas) według kontynentów, wyróżniając Homo europaeus, Homo asiaticus, Homo afer i Homo americanus. Georges-Louis Leclerc de Buffon w 1749 roku zastąpił „odmianę" wywodzącym się z praktyki hodowlanej terminem „rasa”, podkreślając jedność gatunkową i monogenezę ludzi, a jako przyczynę zmienności proponując zwyrodnienie rasy białej (do której należeli oczywiście Adam i Ewa). Jednak największy wpływ na popularyzację klasyfikacji rasowej miał Johann Friedrich Blumenbach, którego podział na pięć ras - kaukazoidalną, negroidalną, mongoloidalną, amerindiańską i malajską - zaproponowany w 1775 roku, bywa stosowany do dzisiaj. Wspomniane klasyfikacje, a także ich późniejsze przekształcenia, wyodrębniające dowolną liczbę ras według swobodnie dobranych kryteriów, miały charakter esencjalistyczny, a opisywane przez nie typy były niezmiennymi wzorcami, którym poszczególne jednostki odpowiadały w mniejszym lub większym stopniu. Dopóki pochodzenie zmienności interpretowano kreacjonistycznie, rasa w zasadzie nie różniła się od gatunku, co było nie do pogodzenia z teorią ewolucji.

Już Karol Darwin był sceptyczny wobec naukowej przydatności kategorii rasy, w dziele The Descent of Man and Selection in Relation to Sex z 1871 roku podkreślał podobieństwa i ciągłą zmienność w obszarze „poszczególnych

R. Miles Racism After"Race Relations", Routledge, London-New York 1993, s. 21.

20 W.J.T. Mitchell Seeing..., s. 21; por. J.P. Sartre Rozważania o kwestii żydowskiej, przeł. J. Lisowski,
Futura Press, Łódź 1992, s. 39-40. 
tak zwanych ras"21. Jednak dopiero od połowy XX wieku paradygmat rasowy zaczął być kwestionowany przez antropologów, aż ostatecznie u schyłku wieku stracił swoją pozycję, szczególnie w obliczu rozwoju badań genetycznych. Zakończony w 2003 roku Projekt Poznania Genomu Ludzkiego nie wykazał, jakoby wśród ludzi współczesnych istniały osobne, klasyfikowalne podgatunki (rasy). Zgodnie z badaniami DNA dwie osoby z określonej populacji są tak samo odmienne genetycznie, jak dowolne dwie osoby z dowolnych dwóch populacji na świecie. Już w 1997 roku Amerykańskie Towarzystwo Antropologiczne (AAA) wezwało rząd do zaprzestania stosowania terminu "rasa” w danych federalnych jako niemającego podstaw naukowych. W badaniu przeprowadzonym wśród jego członków i członkiń w 1999 roku kategorię rasy odrzuciło 69\% antropologów fizycznych i 80\% antropologów kulturowych ${ }^{22}$.

$\mathrm{Na}$ tym tle zrozumiała wydaje się potrzeba odczytania propozycji Mitchella - ujęcia rasy jako medium - w kontekście dyskusji o użyteczności samej kategorii rasy. Badacz mógł pisać jeszcze w 2012 roku: „Żyjemy w czasach, kiedy rasa jest szeroko postrzegana jako mit czy iluzja; kiedy wyszliśmy poza klisze polityki tożsamości, rasowych esencjalizmów i determinizmu biologicznego, wkroczyliśmy w «epokę postrasową»" ${ }^{23}$. Jednocześnie - podkreśla Mitchell - począwszy od lat 80. XX wieku, rasa stała się obiektem refleksji filozoficznej na niespotykaną wcześniej skalę. Już w 1976

21 Darwin rozpoczyna rozdział O rasach ludzkich słowami: „Nie mam zamiaru tu opisywać różnych tzw. ras ludzkich [several so-called races of men], pragnę natomiast prześledzić, jakie znaczenie z punktu widzenia klasyfikacyjnego mają różnice pomiędzy poszczególnymi rasami oraz w jaki sposób różnice te powstały". Korzystam z polskiego wydania pierwszej części dzieła w przekładzie S. Panki O pochodzeniu człowieka, Państwowe Wydawnictwo Rolnicze i Leśne, Warszawa 1959, s. 166.

L. Lieberman How "Caucasoids" Got Such Big Crania and Why They Shrank: From Morton to Rushton, "Current Anthropology" February 2001 Vol. 42, No. 1, s. 69-95. Dostępny online: http:// psychology.uwo.ca/faculty/rushtonpdfs/Lieberman2001CA.pdf (24.06.2015). Zupełnie inaczej wygląda to w Polsce: w ankiecie wykonanej podczas konferencji Polskiego Towarzystwa Antropologicznego w 2001 r. spośród stu respondentów 75\% opowiedziało się za istnieniem klasyfikowalnych biologicznie ras, wskazując jednocześnie następujące definicje rasy: geograficzną (17\%), typologiczną (13\%), populacyjną (35\%), jako podgatunek (3\%), dwa znaczenia (7\%, w tym $5 \%$ "podgatunek" i inne); pozostałe $25 \%$ odrzuciło istnienie biologicznych ras; K.A. Kaszycka, J. Strzałko Race: Tradition and Convenience, or Taxonomic Reality? More on the Race Concept in Polish Anthropology, "Przegląd Antropologiczny - Anthropological Review” 2003 Vol. 66, s. 23-37. Dostępny online: http://anthro.amu.edu.pl/pdf/paar/volo66/o2kasz.pdf (24.06.2015). 
roku Michel Foucault, mówiąc o wykorzystaniu terminu „rasa”, stwierdzał, że "słowo to nie jest oczywiście związane ze stabilnym znaczeniem biologicznym":

Powiemy, [...] że istnieją dwie rasy, kiedy można napisać historię dwóch grup, które nie mają tego samego lokalnego pochodzenia; dwóch grup, które przynajmniej na początku nie mówią tym samym językiem i często nie wyznają tej samej religii; dwóch grup, które utworzyły jedność i całość polityczną [...] tylko za cenę przemocy. [...] Wreszcie, powiemy, że istnieją dwie rasy, kiedy istnieją dwie grupy, które, choć żyją na jednym obszarze, nie zmieszały się ze sobą z powodu różnic, braku symetrii, barier związanych z przywilejami, zwyczajami i prawami, z podziałem bogactw i ze sposobem sprawowania władzy ${ }^{24}$.

Uznając rasę za „metaforę ostatecznej, nieredukowalnej różnicy”, Henry Louis Gates, Jr. pisał w 1985 roku:

„Rasa” jako kryterium w obrębie nauk biologicznych od dawna traktowana jest jako fikcja. Kiedy mówimy o „białej” lub „czarnej”, żydowskiej” lub „aryjskiej rasie”, używamy biologicznie fałszywych pojęć, a mówiąc ogólniej - metafor. [...] „Rasa" udaje obiektywny termin klasyfikujący, podczas gdy naprawdę jest figurą retoryczną ${ }^{25}$.

Gates zaznacza, że „różnica rasowa” występuje między grupami, które najczęściej mają również fundamentalnie odmienne interesy ekonomiczne. Inaczej niż w różnicy płciowej nie obowiązuje w niej sankcja biologii. „Rasa jest ostateczną metaforą różnicy - stwierdza Gates - ponieważ jej zastosowanie cechuje ogromna dowolność"26. Również Toni Morrison odnosiła się do funkcji rasy jako metafory i o jej użyteczności wykraczającej poza znaczenia wytworzone przez dyskursy pseudonaukowe XVIII i XIX wieku:

M. Foucault Trzeba bronić społeczeństwa. Wykłady w Collège de France, 1976, przeł. M. Kowalska, Wydawnictwo KR, Warszawa 1998, s. 82. współczesnej amerykanistyki, red. A. Preis-Smith, Universitas, Kraków 2004, s. 382. Tekst pierwotnie stanowił wstęp do "Critical Inquiry" Autumn, 1985 Vol. 12, No. 1. 
Rasa stała się metaforyczna - jest sposobem odnoszenia się do - i maskowania - sił, wydarzeń, klas, przejawów rozpadu społecznego i podziałów ekonomicznych o wiele bardziej groźnych dla ciała politycznego niż kiedykolwiek była biologiczna „rasa”. [...] Wydaje się, że [rasa] pełni użytek daleko poza ekonomią, poza utrzymywaniem podziału klasowego, i obrała metaforyczne życie tak zakorzenione w codzienności, że być może jest bardziej potrzebna i bardziej wystawiona na widok niż kiedykolwiek wcześniej ${ }^{27}$.

Mitchellowska propozycja ujęcia rasy jako medium, na tym tle, wydaje się rozwinięciem i przeniesieniem do głównego nurtu historii sztuki koncepcji Gatesa i Morrison, wywodzących się z obszaru krytyki literackiej - metafora, przeniesienie, sama jest przecież medium. Nieefektywne okazały się jednak założenia, że rasa to „jedynie metafora” - tym razem przedmiotu badań nie stanowi relacja zmienionych za jej pośrednictwem znaczeń, lecz sam jej „zniekształcający pryzmat”.

Obecnie potrzeba namysłu nad kategorią rasy wydaje się jeszcze bardziej nagląca. Mimo kategorycznego odrzucenia jej przez nauki przyrodnicze i wielu lat krytycznej refleksji w humanistyce w dalszym ciągu pozostaje zasadniczym pryzmatem postrzegania rzeczywistości społecznej, a rasizm bynajmniej nie przestał istnieć. Wręcz przeciwnie - w obecnych czasach doświadczamy plagi urasawiania, w którym kolor skóry nie stanowi już głównego kryterium. Mitchell zwraca uwagę, że ów proces obejmuje zarówno przestrzeń, jak i czas; „nie tylko rzeczy materialne (ciała, budynki, towary, dzieła sztuki), ale też działania i wydarzenia"28. W obliczu „ślepej na kolor" polityki w Stanach Zjednoczonych przełomu wieków pytał: „Dlaczego nasi współobywatele, nie mówiąc o władzach i prawodawcach, dalej postępują tak, jakby rasa nadal miała znaczenie?"29 - co znalazło dobitne potwierdzenie w wyborze Donalda Trumpa na 45. prezydenta USA.

„Trump w swojej kampanii zbił kapitał na wszystkich siłach ciemności drzemiących w elektoracie [...]. Rasizm, mizoginia, ksenofobia, niepokój, żal, paranoja oraz uogólniona nienawiść do elit, ekspertów i uznanych instytucji - wszystkie razem zostały zaprzęgnięte, by wywołać falę zbiorowego

27 T. Morrison Playing in the Dark: Whiteness and the Literary Imagination, Harvard University Press, Cambridge, MA-London 1992, s. 63. 
szaleństwa"30 - pisał Mitchell w dniu ogłoszenia wyników wyborów. Po dwóch kadencjach sprawowania urzędu przez pierwszego czarnego prezydenta w historii Stanów Zjednoczonych, funkcję głowy państwa objął pozbawiony kompetencji politycznych populista popierany przez Ku Klux Klan. „Zatriumfowała pusta retoryka fałszywej siły, oznaka rozpaczy bardziej rozpowszechnionej, niż myśleliśmy" - ubolewała Judith Butler, stawiając gorzkie pytanie:

Kim oni są, ci ludzie, którzy głosowali na niego? Lecz także kim my jesteśmy, skoro nie widzieliśmy ich siły, skoro w ogóle się tego nie spodziewaliśmy, skoro nie mogliśmy pojąć, że ludzie będą głosować na człowieka posługującego się rasistowską i ksenofobiczną retoryką, z historią przestępstw seksualnych i wykorzystywania pracowników, z pogardą dla konstytucji i migrantów, i z lekkomyślnym planem zwiększenia militaryzacji ${ }^{31}$

Filozofka zwraca uwagę, że w swojej kampanii Trump rozbudził stłumiony gniew przeciw feministkom jako zagrożeniu dla wolności słowa; przeciw wielokulturowości jako zagrożeniu dla białego przywileju; przeciw migrantom jako zagrożeniu dla bezpieczeństwa narodowego. Trudno nie zgodzić się z Butler, że wynik wyborów świadczy o awersji do pierwszego czarnego prezydenta, spotęgowanej wściekłością na myśl o elekcji pierwszej kobiety - uczuciami żywionymi przez wielu białych mężczyzn i niektóre kobiety ${ }^{32}$. „Uczyńmy Amerykę znów wielką," hasło kampanii Trumpa, według historyczki Nell Irvin Painter dla wielu brzmiało: „Uczyńmy Amerykę znów białą”. Głosując, wyrażali nadzieję na powrót czasów nieokreślanej przez pryzmat rasy bieli i nienaznaczonej rasowo siły politycznej i ekonomicznej - z założenia białej3. Paradoksalnie wybory 2016 roku w nawet większym stopniu niż

W.J.T. Mitchell Trump's Election and Collective Madness, The Critical Inquiry Blog, 09.11.2016, https://critinq.wordpress.com/2016/11/og/trumps-election-and-collective-madness/ (22.11.2016)..

31 J. Butler, A statement from /udith Butler, e-flux conversations, 09.11.2016, http://conversations.e-flux.com/t/a-statement-from-judith-butler/5215?u=anton (12.11.2016).

32 Tamże.

33 N.I. Painter, What Whiteness Means in the Trump Era, "The New York Times", 12.11.2016, http:// www.nytimes.com/2016/11/13/opinion/what-whiteness-means-in-the-trump-era.html?_r=0 (22.11.2016). 
poprzednie uwidoczniły podziały rasowe w Stanach Zjednoczonych ${ }^{34}$. Szerokie analizy rozkładu głosów białej tożsamości nadały piętno to ż s a m o ś c i r a s o w e ${ }^{35}$. Dla większości białych Amerykanów i Amerykanek bycie białym oznaczało wolność od rasy, kategoryzacji, dylematów wspólnotowości. Jednak teraz nie mogą być już widziani jedynie jako odrębne jednostki, wyrażające swe indywidualne preferencje w życiu i polityce - twierdzi Painter - era Trumpa naznacza ich rasą, białą rasą. Po raz pierwszy biały mężczyzna zwycięża nie tak po prostu, jak niemal zawsze wcześniej, ale jako biały mężczyzna, i jako biały mężczyzna będzie sprawować urząd $\mathrm{d}^{36}$. Po raz pierwszy biała klasa pracująca głosuje jak mniejszość rasowa ${ }^{37}$. W ten sposób z ery postrasowej znajdującej legitymizację w postaci czarnego prezydenta Ameryka wkracza w czasy wszechogarniającej rasowej kategoryzacji i przybierających na sile rasowych antagonizmów. „W świecie, który coraz częściej jest błędnie określany jako postrasowy i postfeministyczny - pisze Butler - teraz widzimy, jak mizoginia i rasizm przesłaniają osąd i przywiązanie do dążeń demokratycznych i integracyjnych - to sadystyczne, pełne żalu, destrukcyjne namiętności napędzające nasz kraj"38.

Jak w 2012 roku zaznaczał Mitchell, choć wciąż najbardziej istotnymi formami rasizmu pozostawały islamofobia, negrofobia i antysemityzm, w Stanach Zjednoczonych właściwie każdy mógł stać się przedmiotem urasowienia, charakterystyki jako grupy, której ciała, psyche, rodowód stanowią zagrożenie dla "prawdziwej Ameryki"39 - co niedługo później miało znaleźć odbicie w kampanii Trumpa. Mitchell zwracał uwagę na lęk przed pozorną identycznością, ukrytym rasowym Innym, i pisał: „Może się okazać, że podobieństwo jest bardziej niebezpieczne niż różnica, że homofobia - dosłownie, strach przed takim samym - i jej postrasowy odpowiednik, klonofobia, jest

Według sondażu Edison Research na D. Trumpa głosowało 63\% białych mężczyzn i $53 \%$ białych kobiet, na H. Clinton 80\% czarnych mężczyzn, 94\% czarnych kobiet, 62 \% Latynoamerykanów, 68\% Latynoamerykanek i 61\% pozostałych osób. Podaję za: CNN politics, 09.11.2016, http://edition.cnn.com/election/results/exit-polls/national/president (22.11.2016).

N.I. Painter, What Witness...op. cit.

Tamże.

N. Cohn, post na Twitterze, 08.11.2016, https://twitter.com/Nate_Cohn/status/796184879704711168 (22.11.2016).

J. Butler, A statement...op. cit.

W.J.T. Mitchell Seeing..., tamże, s. 29. 
jeszcze bardziej groźna niż jakakolwiek obawa przed odmiennością seksualną"40. Rasowy Inny jest definiowany nie tylko na podstawie koloru skóry, ale też pochodzenia etnicznego, narodowości, religii, zachowań i na gruncie moralnym $^{41}$. Szczególne ciekawy jest przywoływany przez Mitchella przypadek Latynoamerykanów (Hispanic or Latino), których przeprowadzające spisy ludności Bureau of the Census definiuje jako „osoby o kubańskiej, meksykańskiej, portorykańskiej, środkowo- lub południowoamerykańskiej, lub innej hiszpańskiej kulturze lub pochodzeniu, niezależnie od rasy", w odróżnieniu od „białych nie o pochodzeniu hiszpańskim” (non-Hispanic whites) ${ }^{42}$. Wywodzący się z bardzo wielu narodowości, związani głównie - i niekoniecznie - językiem, w debatach o imigracji i jej skutkach podlegają urasowieniu i wykluczeniu z grupy białych. W procesie tym ponownie zostają wykorzystane te same stereotypy, którymi tradycyjnie posługuje się wobec czarnych Amerykanów i Amerykanek: przestępczości, analfabetyzmu, zepsucia moralnego ${ }^{43}$. Po tę retorykę miał sięgnąć Donald Trump w swej kampanii wyborczej.

Jako analogiczną wobec współczesnego mechanizmu wykluczenia Latynoamerykanów Mitchell przywołuje opartą na tym samym schemacie logikę hibernofobii.,U/oczernienie” (blackening) jako sposób ustanowienia rasowego Innego było powszechne wobec irlandzkich imigrantów, których w pierwszej połowie XIX wieku określano jako „czarnuchów wywiniętych na lewą stronę"44. Związane to było z sięgającą średniowiecza tradycją dyskryminacji wobec Irlandczyków, uważanych przez Anglików za barbarzyńców żyjących jak zwierzęta. Wiktoriański etnolog John Beddoe w swoim dziele The Races of Britain z 1862 roku uznał - opierając się głównie na analizie kolorów włosów - że rdzenni mieszkańcy Irlandii są w zasadzie „afrykanoidami”. Ilustracja z amerykańskiego czasopisma „Harper's Weekly” z 1899 roku ukazuje „Iroiberyjczyka” (!) jako stadium pośrednie między „Negrem” a „Angloteutończykiem”45.

Tamże, s. 31.

Tamże, s. 29.

U.S. Census Bureau The Hispanic population: 2010, 2011, http://www.census.gov/prod/ cen2010/briefs/c2010br-04.pdf(25.06.2015).

W.J.T. Mitchell Seeing..., s. 29.

N. Ignatiev How the Irish Became White, Routledge, New York-London 1995, s. 41.

Wiązało się to z poglądem, jakoby wszyscy Irlandczycy byli potomkami lberyjczyków (o czym miało świadczyć podobieństwo łacińskich nazw Irlandii i Hiszpanii: Hibernia i lberia), ci z kolei - Afrykanami. 
Urasowienie, które zawsze przyjmowało niespójną i wewnętrznie sprzeczną logikę, obecnie obejmuje niezwykłą różnorodność tożsamości i etniczności. Niezmienna pozostaje natomiast strukturalna potrzeba ustanowienia Innego, wroga. Frantz Fanon swego czasu cytował słowa swojego antylskiego nauczyciela filozofii: „Gdy usłyszysz, że mówią źle o Żydach, nadstaw uszu: mówią o tobie" ${ }^{\prime 46}$. Mitchell, przypominając o swoim irlandzkim pochodzeniu, kieruje przestrogę do innych mniejszości: „kiedy mówią o Arabach i muzułmanach, mówią o nas" ${ }^{47}$.

Jakie jest obecne znaczenie koncepcji rasy, gdy jednocześnie uznawana jest za fałszywą, a jednak każdy i każda, bez względu na kolor skóry i pochodzenie, może zostać poddany urasowieniu? W Stanach Zjednoczonych nie ma potrzeby urasawiać czarnych: ich odmienność jest wizualnie oczywista, instytucjonalny rasizm - silny, a wybór czarnego prezydenta oddalił na chwilę pytanie o powszechność dyskryminacji. Urasowienie przyjmuje teraz inne formy, nie tylko "uczernienia”, ale też zamazywania tożsamości, anonimowości, zasłonięcia czy pozbawienia twarzy, nieszczerej życzliwości - jak w stereotypie islamskiego terrorysty ${ }^{48}$. Oczywiście nie dotyczy to tylko Stanów Zjednoczonych, lecz w coraz większym stopniu - zmagającej się z kryzysem uchodźczym Europy. Nasze lokalne przedmurze chrześcijaństwa w obliczu nowego arabskiego podboju zwraca się ku tej samej retoryce w jej najgorszych przejawach, nie porzucając własnych bogatych tradycji antysemityzmu i ksenofobii. Niepokojąco rośnie liczba ataków powodowanych rasizmem a obejmujących przedstawicieli dowolnych kultur i etniczności. Wszystko wskazuje na to, co przewidywał Mitchell: epoka postrasowa paradoksalnie przeobraziła się w obejmującą cały świat zachodni epokę panrasową. Kiedy nie ma stabilnego rasowego Innego, wiarygodnej „linii koloru”, anonimowym wrogiem staje się obojętnie kto i obojętnie gdzie - czy to Meksykanie, czy ISIS - a jego nieuchwytna obecność legitymizuje wzrastającą agresję władzy. „W ten sposób ochrypła pieśń ras, które ścierają się ze sobą poprzez kłamstwa praw i królów - kończył cytowany już wcześniej wykład Foucault - ta pieśń, która przyniosła przecież pierwszą formę dyskursu rewolucyjnego, stała się

46 F. Fanon Czarna skóra, białe maski, przeł. L. Magnone, maszynopis, s. 9. Udostępniony przez tłumaczkę na portalu Academia.edu: http://www.academia.edu/7917101/ (06.07.2015), pierwotnie opublikowany w: Studia postkolonialne nad kulturą i cywilizacją polską, red. K. Stępnik, D. Trześniowski, Wydawnictwo Uniwersytetu Marii Curie-Skłodowskiej, Lublin 2010, s. 359-379. W.J.T. Mitchell Seeing..., s. 9. 
administracyjną prozą państwa, które strzeże samego siebie w imię czystości społecznego dziedzictwa"49.

\section{Abstract}

\section{Jacek Zwierzyński}

ADAM MICKIEWICZ UNIVERSITY (POZNAŃ)

Race as a Medium

In his book Seeing Through Race (2012) W.J.T. Mitchell rethinks race by drawing on studies on visual culture and iconology. Accepting race as both illusion and reality, Mitchell conceptualizes race as a medium, as an ensemble of cognitive filters that are inscribed in the gaze and through which seeing takes place. His argument must be seen in the context of the debate on the usefulness of the very category of race. Rejected by the life sciences and critiqued within the humanities, race is still an important prism through which we see our social reality, nor has racism disappeared. As a product of racism, race can, in Mitchell's view, serve as a window onto the elusive and complex dynamics of this ideology.

\section{Keywords}

W.E.B. Du Bois, iconology, critical race theory, W.J.T. Mitchell, racism

49 W odniesieniu do nazistowskiego i sowieckiego przekształcenia rasizmu; M. Foucault Trzeba bronić społeczeństwa, s. 88. 